The Pakistan Development Review

38 : 4 Part II (Winter 1999) pp. 937-954

\title{
Do Private Schools Produce More Productive Workers?
}

\author{
ZAFAR MUEEN NASIR
}

\section{INTRODUCTION}

Education has positive links with economic development as it raises the productivity of the work force. Beside private rates of returns, the social returns of education are also high. Because of the gains to society, education is subsidised in many countries. Pakistan, where only 2.5 percent of the GDP is spent on education, provides subsidised education in the form of a public school system. ${ }^{1}$ Government pays for the major expenditures such as construction of infrastructure for education and salaries to the teaching and related staff. Household cost is kept low to attract more people to send their children to schools. Therefore only a nominal tuition fee is being charged for attending these schools.

From the social point of view these schools are doing a good job in achieving the goal of universal education. But quality of education is a serious problem with this school system. In the majority of the cases, these are crowded with students and most of the time without adequate number of teaching staff. ${ }^{2}$ The standards set for the employment of teaching staff are not properly observed in the presence of a low literacy in the country. The pay scales offered to the teaching staff are also not very attractive. On top of this, there are no monetary or non-monetary incentives for teachers to

Zafar Mueen Nasir is Senior Research Economist at the Pakistan Institute of Development Economics, Islamabad.

${ }^{1}$ The share of education in the budget is quite low because the minimum recommended by UNESCO is 4 percent of the GDP. This is one of the reasons of low literacy rates and poverty in the country [for further details, please see Yaqoob (1997)].

${ }^{2}$ In Pakistan, public schools are of two types. Those, which are run by some institutions and others, which are, run by the education departments. The schools, which are run by institutions, are well disciplined and provide education comparable to private institutions. Similarly they charge very high fee and have enough funds to run their operation. The problems discussed in the paper are mainly with the public schools being run by the education departments. One of the reasons for these problems is the inadequate fund available to these departments due to financial constraints faced by the government. 
improve their qualification. Therefore teachers show little or no interest in their job. There is no system to monitor the performance of these schools and therefore dropout rates are very high. These schools follow an outdated syllabus, which has no match with the current needs of the labour market.

In contrast to these schools, a large number of private schools also cater to the needs of the population. Most of these schools charge high fee and follow the syllabus being used in developed countries. They are generally equipped with the latest educational equipment like computers and have modern libraries. Moreover students of these schools are involved in many extra curricular activities, which enhances their selfesteem, motivation and abilities. The student-teacher ratio is also kept low to provide quality education. ${ }^{3}$ In addition to this, these private schools are located close to homes where parents can involve themselves in the activities of their children at school. ${ }^{4}$

In the past however, parents preferred public to private institutions. Students who could not get admission in public schools went to enroll in private schools. The main consideration was the high cost of private education. Only affluent parents to sent their children to private schools as could pay the high cost to provide quality education to their children. The number of private institutions was also limited them.

The trend has been changing rapidly after government's policy to open the education sector to private investment. This policy resulted in the emergence of a large number of good institutions in the private sector. Due to the good performance of the students of these schools in different exams, most of the parents consider them better than public schools. ${ }^{5}$ That is the reason enrollment in these schools has been increasing. The system has now spread to the rural areas also where this phenomenon was nonexistent in the near past.

What differentiates these schools from those in the public sector is the theme of this research. The questions to be answered are whether private schools contribute positively to a worker's earnings? Is there any difference in the rate of return for public and private school graduates? The answers to these questions have long-term implications for education in Pakistan as now the private sector is allowed to invest in higher and professional education also. The study is first of its kind to evaluate the

${ }^{3}$ The student teacher ratio in public schools (primary level) was 48 in 1997-98 whereas it was only 23 in private schools.

${ }^{4}$ Average time spent in commuting is 15 minutes for private schools students whereas it is more than one hour for public school attendees.

${ }^{5}$ There are some studies in different parts of the world, which consider the quality of private and public schools. For example, Coleman et al. (1982) found that private schools attendees had acquired more cognitive skills compared to public schools in the United States. Similarly, Jimenez, Lockheed and Paqueo (1989) found support for private school quality in the international setting. In another paper, Jimenez, Lockheed, Luna, and Paqueo (1989) found effectiveness of private schools for quality education for Dominican Republic. 
performance of public and private schools in the context of the labour market.

There are many studies in Pakistan, which have focus on returns to education. Hamdani (1977) used Rawalpindi city data to calculate the private rate of return to education and found high returns to education. The other study by Khan and Irfan (1985) used Population, Migration, and Labour Force (1979) data to investigate the issue at the national level. They also found positive correlation between earnings and education. Shabbir (1991) focused his study on the screening hypothesis and found that there were high returns to completed diplomas. He found about 10 percent returns to each completed year of education.

Because of the data problems, these studies did not address the role of private schools in returns to education. The present study will not only update the work of these studies but will provide additional information regarding returns to education of private and public school system. The paper is structured as follows. Section I provides the introduction, Section II deals with the theoretical model and data. Some stylised facts and empirical results are presented in Section III and the main findings with policy implications are summarised in Section V. Some caveats are also discussed in the last section.

\section{THE EARNINGS MODEL AND DATA CHARACTERISTICS}

The focus of this study is to analyse the effect of school quality on earnings. For that purpose two types of schools have been identified i.e. government run schools and privately run schools. An earning function is being used at the first stage for the overall sample with private school attendance dummy. An extended Mincerian type earnings function is utilised which controls for human capital, personal characteristics, occupation, industry association, and other characteristics. The general form of the model is

$L Y=f(H C, P, I, O, P S C H) \quad \ldots \quad \ldots \quad \ldots \quad \ldots \quad \ldots \quad \ldots$

where $L Y$ represents the log of monthly earnings, $H C$ measures the impact of human capital variables, $P$ is used for the wage related personal characteristics, $I$ for the industry association, $O$ for the occupation of workers, and $P S C H$ for the impact of private school attendance. Human capital variables include education, experience and training of the workers. These traits of the workers are positively linked with earnings under the standard assumptions. ${ }^{6}$ A quadratic term for experience is included to capture the diminishing returns with experience.

The term $P$ includes marital status of the workers, where married people are assumed to be earning a positive premium. This term is included in the model because

${ }^{6} \mathrm{~A}$ wide range of literature exists on this issue. For example see, Becker (1974) and Mincer (1974) and others. 
many studies on U.S. workers found positive returns for married workers. A dichotomous variable for the self-employed is also included in the model. The coefficient of this variable however will give the combined effect of education and capital investment. ${ }^{7}$ Other variables such as urban location and gender are included to capture the effect of regional disparities and gender discrimination. An ordinary least squared estimation technique is applied for the analysis. The definition of the variables is provided in Table 1.

Table 1

\section{Definition of the Variables and Descriptive Statistics by Type of School}

\begin{tabular}{llcc}
\hline Variable & Definition & Private & Public \\
\hline LW & Natural log of monthly earnings & 8.2178 & 7.8312 \\
Age & Years & 32.23 & 33.95 \\
Education & Years of completed education & 11 & 8.7027 \\
Experience & Age-Education-Age started school & 16.83 & 19.82 \\
Experience & Experience squared & 417.58 & 566.11 \\
Male & $=1$ if worker is male & 0.878 & 0.9188 \\
Married & $=1$ if worker is married and spouse present & 0.5575 & 0.6436 \\
Training & $=1$ if worker received training & 0.1979 & 0.2705 \\
Managerial Worker & $=1$ if worker has managerial occupation & 0.1649 & 0.0731 \\
Profession Worker & $=1$ if worker is professional worker & 0.207 & 0.1318 \\
Service Worker & $=1$ if worker is professional worker & 0.1649 & 0.1966 \\
Skilled Labour & $=1$ if classified as skilled worker & 0.0491 & 0.0733 \\
Clerical Worker & $=1$ if worker is clerk & 0.0526 & 0.0704 \\
Financial Industry & $=1$ if worker is employed in financial industry & 0.1434 & 0.1588 \\
Manufacturing & $=1$ if worker is employed in manufacturing industry & 0.1888 & 0.1625 \\
Transport & $=1$ if worker is employed in transport industry & 0.1049 & 0.0873 \\
Social Service & $=1$ if worker is employed in social service industry & 0.2937 & 0.2924 \\
Self-employed & $=1$ if worker is self-employed & 0.2727 & 0.3025 \\
\hline
\end{tabular}

In the second stage we decompose the wage gap of government and private school attendees in their endowments i.e. due to human capital and other characteristics and the wage structure. The Oaxaca (1973) decomposition technique with un-weighted averages is being used for this purpose. The following equation present this technique:

$$
\overline{L Y}_{p}-\overline{L Y}_{g}=0.5 \sum\left(\beta_{p}+\beta_{g}\right)\left(\bar{Z}_{p}-\bar{Z}_{g}\right)+0.5 \sum\left(\bar{Z}_{p}+\bar{Z}_{g}\right)\left(\beta_{p}-\beta_{g}\right) \quad \ldots
$$

The $\beta$ 's in Equation (2) represent the coefficients to be estimated and $Z$ 's refers to the vector of regressors used in the earnings functions. The subscript $p$ and $g$ are used to identify the private and government schools attendees respectively. The bars on the

${ }^{7}$ For more dissuasion, please see Hamdani (1977) and Haque (1977). 
variables indicate the mean values of the variables used in the equations. Finally the terms $\overline{L Y_{p}}$ and $\overline{L Y_{g}}$ represent the mean of log monthly earnings of workers who attended private and public schools in the past.

The data employed in the study is drawn from the Pakistan Integrated Household Survey (PIHS) 1995-96. This survey will have two more rounds till 1999. The Federal Bureau of Statistics has collected the information for the purpose of monitoring and evaluating the Social Action Programme (SAP) of the government. The fieldwork was started in July 1995 and completed in June 1996 and the first report was published in 1997. The data set is nationally representative and covers a sample of 12,800 households of urban and rural areas.

The data set contains information on a variety of topics such as education, health, employment, income and consumption. There are many details about education, wages, occupations and other labour market indicators. The unique aspect of the data on education is the reporting of information in completed years instead of levels, which has been a common approach in the past. The information on the age starting school available in the data combined with years of schooling is utilised to calculate the potential experience of the labour market. ${ }^{8}$ The data set also provides information about the types of schools attended by the worker. This information is particularly important to establish the role of different schools in determining workers' earnings.

The sample to be used in the study is selected from the main data files by imposing some restrictions. First, only those workers of age 10 and above who reported positive earnings are selected. Because of the concentration of private schools in urban areas, we restricted the sample to only urban areas. Some observations were dropped due to inconsistency. The final sample includes 5238 individuals, with 4916 graduates of public schools and 338 of private schools. ${ }^{9}$ The definition and summary statistics of the variables used in the analysis by school type are presented in Table 1 to highlight the characteristics of the sample.

The statistics reveal that the graduates of private schools in Pakistan receive higher earnings relative to workers who graduated from public schools. On an average, graduates from private schools are relatively young and have more years of education than their counterparts from public schools. A small percentage of private school graduates also received technical or vocational training. The majority of these individuals is either professional or administrative workers. The data indicate that the private school graduates have a higher percentage of single workers compared to public

${ }^{8}$ According to Mincer (1974), the labour market experience can be calculated as age-education-6. Because the school going age in Pakistan varies across regions, the subtraction of 6 is misleading. As our survey has this particular information, we can use this to overcome the problem.

${ }^{9}$ The information about education from public and private schools collected for the first time by this survey. Because of this problem we are constrained with small sample size. 
schools attendees. Because of their young age, the workforce graduated from private schools has less job experience compared to public school graduates.

To further highlight, some of the differences in the earnings by different traits of workers are presented in Section III as stylised facts.

\section{STYLISED FACTS AND EMPIRICAL RESULTS}

The average monthly earnings of workers in different age groups are presented in Table 2. As expected, the earnings increase with age for workers, irrespective of their educational institution. However, it is noted that the earnings increase more rapidly for those who graduated from private schools. It is interesting to note that, on an average, the worker who received education in private schools received 83 percent more than his counterpart who graduated from a government run school. The statistics further reveal that the monthly earnings of public and private school graduates increased with age. The earnings of public school attendees however show decline after the age 50 whereas the earnings of private school attendees does not show declining trend with age. ${ }^{10}$

Table 2

Monthly Earnings of Workers by Age Groups and School Type

\begin{tabular}{lcc}
\hline \multirow{2}{*}{ Variable } & \multicolumn{2}{c}{ School Type } \\
\cline { 2 - 3 } Age 10-20 & Public & Private \\
Age 21-30 & 2831.02 & 1367.96 \\
Age 31-40 & 4302.85 & 4812.63 \\
Age 41-50 & 5741.20 & 8708.11 \\
Age 51-60 & 5420.60 & 8582.82 \\
Age 61+ & 4534.63 & 14238.00 \\
\hline
\end{tabular}

Table 3 provides the average monthly earnings of workers by educational achievements. The table shows that less than 10 years of schooling brings higher earnings for those who attended government schools compared to private school graduates. The earnings are however much higher for private school graduates with 10 or higher years of education compared to public school graduates. The low earnings

${ }^{10}$ The number of observations in the last group are low therefore the result of this age-group may not be very reliable. 
of private school attendees for less than 10 years of schooling suggest that there is no advantage for dropouts even if they attended quality schools.

Table 3

Monthly Earnings of Workers by Education and School Type

\begin{tabular}{lcc}
\hline \multirow{2}{*}{ Variable } & \multicolumn{2}{c}{ School Type } \\
\cline { 2 - 3 } & Public & Private \\
\hline Education $<10$ Years & 2643.25 & 2413.73 \\
& $(28.20)$ & $(51.63)$ \\
Education 10 Years & 3860.31 & 5149.68 \\
& $(30.45)$ & $(31.53)$ \\
Education $>10 \&<13$ Years & 6093.87 & 10999.18 \\
& $(22.93)$ & $(9.59)$ \\
Education Degree & 8261.02 & 12853.06 \\
& $(18.42)$ & $(7.25)$ \\
\hline
\end{tabular}

Note: Figures in parenthesis are the percentage distribution of workers in particular school system.

Education is linked with the motivation to work and consistency in the behaviour besides providing productivity enhancing skills. The completion of some programme reflects the motivation and consistency of the behaviour [Arrow (1973) and Spence (1974)]. The dropping-out before completion of secondary certificate (the first diploma provided by an officially constituted board) shows lack of motivation and inconsistency in the behaviour on the part of the worker even if he attended a high quality private school. Because of this reason they did not get into high paying jobs and got stuck in structurally low paying professions. ${ }^{11}$ Therefore they earn lower wages compared to their counterparts from public school system. The public school attendees who could not complete 10 years of education are at the advantageous position as they not only have accumulated more experience in the labour market but received some training also.

The distribution of workers of public and private school graduates in different occupations with their monthly earnings is provided in the Table 4 . The statistics indicate that the difference in earnings between public and private school attendees is quite high for professions associated with higher education. It is noted that 50 percent of private school graduates are either managerial and administrative workers or professionals compared to 25 percent of public school attendees. Private school graduates who work as managers or administrators earn 68 percent higher than the public school graduates in the same occupation. Similarly professional workers who graduated from private schools earned 77 percent higher wages compared to their

\footnotetext{
${ }^{11}$ The other success of the private schools is their ability to retain more students (73 percent) compared to public schools system ( 38 percent) to complete higher education (10 and above).
} 
Table 4

Monthly Earnings of Workers in Different Industries by School Type

\begin{tabular}{lcc}
\hline \multirow{2}{*}{ Variable } & \multicolumn{2}{c}{ School Type } \\
\cline { 2 - 3 } Managerial Workers & Public & Private \\
\hline & 8113.41 & 12984.04 \\
Professional Workers & $(7.30)$ & $(16.49)$ \\
Clerical Workers & 4901.23 & 9828.91 \\
& $(17.41)$ & $(22.46)$ \\
Service Workers & 3327.41 & 3486.67 \\
& $(7.03)$ & $(5.26)$ \\
Craftsmen & 3369.63 & 3658.85 \\
& $(19.66)$ & $(16.49)$ \\
Other Occupations & 2604.81 & 2651.48 \\
& $(23.58)$ & $(18.25)$ \\
\end{tabular}

The further evidence of private schools' role in allocation of high paying jobs is depicted in Table 5 which presents average monthly earnings of workers in different industries by school type. Workers who graduated from private schools received higher monthly earnings in the same industry than workers who had education from government-run schools. The earnings are higher for private school graduates in all industries compared to the workers who graduated from public school system. This means that school quality is also instrumental in sorting workers into different sectors of employment with private school graduates getting jobs in the high paying sector.

Keeping these stylised facts in view, it is evident that private schools graduates earn higher income in Pakistan's labour market compared to public school attendees. The factors contributing more to the difference in the earnings by school type are analysed in the next section. The earnings differential is also calculated based on these factors. The results are based on different regression equations presented in the next section.

The estimated coefficients, associated with human and non-human capital variables, of regression equations are presented in Table 6. For all workers, the coefficient associated with private school variable indicates that workers receive 30 percent high returns if they attended private schools in the past. ${ }^{1}$ These returns are significant at 99 percent confidence level. This implies that education at private schools significantly affects the earnings in the Pakistani labour market. To chow test was

${ }^{1}$ The returns to private school attendance are calculated (in percentage form) by taking the anti$\log$ of 0.263 (the estimated coefficient of private school attendance), subtracting one and multiplying 100 . For further details, please see Gujarati (1988), p. 149. 
Table 5

Monthly Earnings of Workers in Different Industries by School Type

\begin{tabular}{lcc}
\hline \multirow{2}{*}{ Industry } & \multicolumn{2}{c}{ School Type } \\
\cline { 2 - 3 } Electricity, Gas, Water and Construction & 3434.90 & Private \\
Finance & $(22.10)$ & 5716.23 \\
& 5058.61 & $(19.52)$ \\
Manufacturing & $(14.97)$ & 11960.98 \\
& 2927.95 & $(14.04)$ \\
Personal Services & $(15.35)$ & 8258.89 \\
& 4265.10 & $(18.49)$ \\
Social Services & $(11.65)$ & 9583.08 \\
& 3351.79 & $(8.90)$ \\
Transport & $(27.69)$ & 3818.27 \\
& 3633.41 & $(28.77)$ \\
& $(8.23)$ & 7610.00 \\
\end{tabular}

Table 6

Coefficients of OLS Estimates for Different Schools Types

\begin{tabular}{|c|c|c|c|c|c|c|}
\hline \multirow[b]{2}{*}{ Variables } & \multicolumn{2}{|c|}{ Full Sample } & \multicolumn{2}{|c|}{ Private Schools } & \multicolumn{2}{|c|}{ Public Schools } \\
\hline & Coefficient & $t$-ratio & Coefficient & $t$-ratio & Coefficient & $t$-ratio \\
\hline Constant & $5.4660 *$ & 96.27 & $5.2810^{*}$ & 18.67 & $5.5080 *$ & 94.93 \\
\hline Education & $0.0943^{*}$ & 32.86 & $0.1330 *$ & 9.54 & $0.0915^{*}$ & 31.21 \\
\hline Experience & $0.0542 *$ & 17.99 & $0.1050^{*}$ & 5.92 & $0.0510^{*}$ & 16.71 \\
\hline Experience $^{2}$ & $-0.00073^{*}$ & -14.01 & $-0.00153^{*}$ & -4.32 & $-0.00068^{*}$ & -13.06 \\
\hline Male & $0.6640^{*}$ & 17.11 & 0.2890 & 1.71 & $0.6810^{*}$ & 17.07 \\
\hline Married & $0.0927 *$ & 3.24 & -0.2040 & -1.39 & $0.1070^{*}$ & 3.66 \\
\hline Training & $0.0295^{*}$ & 2.30 & 0.0152 & 1.54 & $0.0295^{*}$ & 2.28 \\
\hline Managerial Worker & $0.3850^{*}$ & 9.46 & $0.6230^{*}$ & 3.81 & $0.3680 *$ & 8.71 \\
\hline Professional Worker & $0.2680^{*}$ & 7.99 & $0.3900^{*}$ & 2.58 & $0.2730 *$ & 7.94 \\
\hline Service Worker & 0.0246 & 0.82 & 0.1270 & 0.77 & 0.0170 & 0.56 \\
\hline Other Skilled Labour & $0.1980 *$ & 4.66 & 0.3060 & 1.24 & $0.1920^{*}$ & 4.47 \\
\hline Clerical Worker & 0.0038 & 0.09 & 0.1260 & 0.55 & 0.0106 & 0.25 \\
\hline Financial Industry & $0.1160 *$ & 3.50 & -0.0543 & -0.30 & $0.1110^{*}$ & 3.31 \\
\hline Manufacturing Industry & -0.0297 & -0.88 & 0.1090 & 0.66 & -0.0476 & -1.39 \\
\hline Transport Industry & 0.0649 & 1.54 & -0.0892 & -0.48 & 0.0678 & 1.57 \\
\hline Social Service Industry & 0.0131 & 0.46 & -0.2580 & -1.66 & 0.0259 & 0.91 \\
\hline Self-employed & $0.3420 *$ & 14.28 & $0.2880^{*}$ & 2.47 & $0.3450^{*}$ & 14.13 \\
\hline Private School & $0.2630^{*}$ & 5.85 & - & - & - & - \\
\hline Adj $R^{2}$ & \multicolumn{2}{|c|}{0.4400} & \multicolumn{2}{|c|}{0.5780} & \multicolumn{2}{|c|}{0.4260} \\
\hline F-Statistics & \multicolumn{2}{|c|}{242.02} & \multicolumn{2}{|c|}{23.54} & \multicolumn{2}{|c|}{229.98} \\
\hline Sample & \multicolumn{2}{|c|}{5215} & \multicolumn{2}{|c|}{263} & \multicolumn{2}{|c|}{4952} \\
\hline
\end{tabular}


applied to see the structural difference between the worker who attended public and private schools. The calculated $F_{(17,5198)}$ is greater then the critical value of $F$. This strengthens the point that public and private school graduates receive different treatment in Pakistani labour market. We therefore included separate equations for public and private school graduates.

The statistically significant coefficients of education and experience indicate that these are the important determinant of earnings for both public and private school attendees. For private school graduates, an additional year of schooling raises the earnings by 14.2 percent whereas it contributes only 9.6 percent additional earnings for public school graduates. The high returns to education for private school attendees indicates that the workers get those skills by attending private schools which are more valued by the employer.

The labour market experience also raises the earnings of workers significantly for both groups. However the benefits are much higher for private school attendees as they experience a steeper earnings growth. More specifically, a worker who attended private school receives 62.7 percent earnings premium with five year of experience against 26.9 percent wage premium for public school attendance. Similarly, 10 years of experience in the labour market increases the earnings by more than 100 percent for private school attendees but only 55.6 percent for public school graduates. Moreover, the earnings with experience for private school graduates reach at the peak at a much later stage then for public school graduates.

Because earnings are related to the marginal productivity of workers in a competitive setup therefore the high returns to human capital variables suggest that private schools are more successful in enhancing the productivity of workers by providing them quality education. This also reflects the fact that better school quality helps to learn skills more quickly, which brings higher returns for the workers in the labour market. ${ }^{2}$ This indirect effect of private schools is through acquiring more cognitive skills, which not only motivate workers but also induce them to actively participate in job activities and learn more job related skills. That is one of the reasons they receive high returns for each year of experience. In general, our results are consistent with the human capital theory and prior studies on Pakistan [Shabbir (1991, 1994)].

The coefficient of training is positive for both types of school attendees and indicates that other things being equal those who received any sort of training, tend to earn more. The magnitude of the coefficient however is higher for public school attendees compared to private school attendees for whom it is statistically insignificant. Similar to training, the coefficient of marriage is also significant (statistically) for public school graduates. Married workers with education from public schools earn 11 percent

${ }^{2}$ Coleman, Hoffer and Kilgore (1982); Jimenez, Lockheed and Paqueo (1989) found that students learn more skills in private schools compared to public schools. 
more than single workers or those currently not living with their spouse. ${ }^{3}$ These findings for government school attendees explain some of the differences in the monthly earnings noted in Table 3 for those who could not complete 10 years of education. The marriage premium is in-line with other studies, which found positive premium for workers [Becker (1981, 1985); Kenny (1983); Greenhalgh (1980), Burki (1997) and Nasir (1999)]. The motivation, handwork, and seriousness with the job are some of the characteristics associated with marriage, which enhances their productivity and substitute for some of the differences which arise due to private school attendance. The insignificant coefficient for private school attendees may suggest that these workers already enjoy most of the benefits which marriage brings for public school graduates.

We included dummies for different occupations to see their relevance in explaining the earnings of workers in both groups. Our results indicate that all occupations are positively related with earnings for both groups. However, only a few of them have statistical significance. Importantly, there are statistically significant returns for managerial and professional workers for both groups. However, the premium is relatively high for private school graduates. Managerial workers earn approximately 86.5 percent and professional workers earn 47.7 percent higher premium compared to labour (excluded category) if they attended private schools in the past. In comparison, the returns are 44.5 percent and 31.4 percent for managerial and professional workers respectively, if they attended public school. The skilled labour also has earnings advantage if they attended public schools. Most of these workers are less educated and receive higher earnings due to training and labour market experience, which generates valuable skills.

The industry association is not very important for private school attendees. However, only financial industry has some relevance for public school attendees. The coefficient of self-employment is statistically significant for both groups. The returns are, however, high for public school graduates compared to private school graduates. Individuals in this category earn 41 percent higher compared to regular employees. This earning difference could be attributed to the returns to the capital investment rather than returns to human capital factors.

Finally, the role of gender has been explored by using a dummy for male workers. The coefficient for this variable point out the significant wage discrimination against females but the incident of discrimination is relatively small if they have attended private schools. An average female worker who attended private school earns approximately 33.5 percent less than her male counterpart whereas the earnings for males are 97.6 percent higher than the females who attended public schools. This is a very important finding as it provides a way to reduce gender discrimination.

\footnotetext{
${ }^{3}$ The excluded category include widow, divorced, separated, and single workers.
} 


\section{Decomposition of Earnings Differentials}

The earnings differential of workers having schooling from private and public school system is decomposed into two parts i.e. due to workers' average endowments and due to difference in wage structure. The results of this decomposition analysis are presented in Table 7. To calculate the difference due to wage structure, estimated coefficients of public and private school equations are used. For the difference due to endowments, average weights of human and nonhuman capital variables are used.

Our results indicate that human capital attributes of workers play important role in the higher wages of private school attendees. Private school graduates not only benefit due to their superior human capital endowment but also due to high returns on these attributes. The decomposition of earnings suggests that years of schooling benefit private school graduates both due to endowment and due to the wage structure. As endowment, the benefits of experience and training however go to the public school graduates but private school graduates benefit due to their superior wage structure.

Table 7

Decomposition of Earnings Difference of Private and Public School Attendees

\begin{tabular}{lccc}
\hline Variable & Endowments & Structure of Payments & Total \\
\hline $\mathrm{C}$ & 0 & -0.2270 & -0.227 \\
Education & 0.2579 & 0.4088 & 0.6667 \\
Experience & -0.0689 & 0.5715 & 0.5026 \\
Male & -0.0198 & -0.3522 & -0.372 \\
Married & 0.0042 & -0.1868 & -0.1826 \\
Training & -0.0162 & 0.0287 & 0.0125 \\
Occupation & 0.4703 & 0.0841 & 0.1311 \\
Industry & 0.000031 & -0.0958 & -0.0957 \\
Self-employed & -0.00943 & -0.0164 & -0.0258 \\
Total & 0.1948 & 0.2149 & 0.4098 \\
\hline
\end{tabular}

There is no premium associated with marriage, self-employment, and sex being male for private school graduates. The occupation of the private school attendees affects wages through both factors i.e. due to endowment and due to wage structure but industry association helps only due to the superior endowment of private school graduates. At the overall level, private school attendees benefit not only due to superior endowment but also due to wage structure. 


\section{CONCLUSIONS, POLICY IMPLICATIONS AND CAVEATS}

The paper uses Pakistan Integrated Economic Survey data 1995-96 to study the impact of private school attendance on earnings. It not only compares the earnings of private school attendees with public school attendees but also decomposes the earnings into two parts i.e. due to endowment and due to structure of payment. This information is useful in understanding the mechanism through which private schools attendees receive higher earnings.

The results show that private school attendees receive higher earnings in the labour market compared to government-run schools. The higher earnings for private school graduates are the reflection of quality and skills which workers accumulate by attending these schools. The earnings advantage of public school graduates for less than 10 years of education is the result of their relatively more training and experience in the labour market. The higher earnings of private school attendees in different professions and industries suggests that private school attendance is instrumental in sorting workers into high paying occupations and industries. Our results indicate that private school attendance reduces the discrimination against female workers in the labour market. These are very important findings and government can adopt a policy to provide quality education in the public school system to help workers to get high paying jobs as well as reducing the incidence of discrimination against female workers.

The decomposition analysis suggests that private school attendees not only benefit from superior human capital endowment but also due to the structure of the payment. Both factors benefit private school attendees almost equally. The major players for these high earnings differential for private school graduates are the human capital factors (education and experience). These factors outweigh the effect of other factors included in the analysis.

The findings of the study clearly suggest that private schools produce more productive workers by providing them quality education. These schools are expensive but more effective in generating the skills valued in the labour market. The approach adopted by these schools is a model for the public school system and policy makers can adopt this approach to overhaul the existing ineffective educational system of the country.

Some important steps, which can enhance the effectiveness of the public school system, include the revision of the outdated curriculum currently used by government schools. The new curriculum could be developed by focusing on the current and future needs of the national and international labour markets. The other important step in this direction is the revamping of the selection process of teaching staff. A policy should be made at the national level to attract the most able people to the teaching profession. For that, not only their remuneration should be reconsidered 
but their status in the society should also be raised. An extensive training programme could help them in effective teaching methods. An incentive-based system should be adopted to encourage them to participate in the learning process.

Computer facilities and better libraries are also the need of the time. The way computer is entering in everyday life is not a secret anymore. Another important development of science is the Internet, which is the quickest and easiest medium of information. This is revolutionising the world of business and education. If workers will not be equipped with the latest developments at the global level, there are chances that we will miss the opportunity to develop our country. Well-equipped libraries are essential for inculcating reading habit, so essential to the understanding of concepts. If policy-makers overlook the changes that are taking place at the global level, we will never be able to compete globally.

\section{Caveats}

Although our results are drawn from a nationally representative sample, the sample for private school is small. Because of the small sample some of the categories included in the analysis may not have enough observation to represent that particular category adequately. Secondly, the paper ignores the parental characteristics and family background of the workers, which may have biased our result. The reason for not adjusting for bias is the data limitation. The survey does not include information on the parental characteristics and other background information necessary for this purpose.

\section{REFERENCES}

Arrow, K. (1973) Higher Education as a Filter. Journal of Public Economics 2:3 193-216.

Becker, Gary S. (1974) Human Capital. New York : National Bureau of Economic Research.

Becker, Gary S. (1981) A Treatise on the Family. Cambridge: Harvard University Press.

Becker, Gary S. (1985) Human Capital, Effort, and the Sexual Division of Labour. Journal of Labour Economics 3: 33-58.

Burki, A. A. (1997) Wage Determination in Pakistan's Small Manufacturing Sector: Subcontracting vs Non-subcontracting Firms, Regional Workshop on Return Migration and Long-term Economic Development in South Asia. Quaid-i-Azam University, Islamabad.

Coleman, J., T. Hoffer, and S. Kilgore (1982) High School Achievement: Public, Catholic and Private Schools Compared. New York: Basic.

Greenhalgh, Christine (1980) Male-female Wage Differential in Great Britain: Is 
Marriage an Equal Opportunity? Economic Journal 90: 751-775.

Gujrati, Damodar N. (1988) Basic Econometrics (2nd edition). New York: Mac Graw-Hill, Inc.

Hamdani, Khalil A. (1977) Education and the Income Differential: An Estimation for Rawalpindi City. The Pakistan Development Review 26:2 144-164.

Haque, Nadeem ul (1977) Economic Analysis of Personal Earnings in Rawalpindi City. The Pakistan Development Review 26:4 687-696.

Jimenez, E., M. E. Lockheed, and V. Paqueo (1988) The Relative Efficiency of Public Schools in Developing Countries. Education and Training Department, World Bank, Washington, D. C. (Working Paper WPS 72.)

Jimenez, E., M. E. Lockheed, E. Luna, and V. Paqueo (1989) School Effects and Costs for Private and Public Schools in the Dominican Republic. Education and Employment Department, World Bank, Washington, D. C. (Working Paper WPS 288.)

Kenny, Lawrence (1983) The Accumulation of Human Capital During Marriage by Males. Economic Inquiry 21: 223-231.

Khan, Shahrukh Rafi, and Mohammad Irfan (1985) Rate of Returns to Education and the Determinants of Earnings in Pakistan. The Pakistan Development Review 24:3\&4 471-680.

Mincer, Jacob (1974) Schooling, Experience and Earnings. New York: Columbia University Press.

Nasir, Zafar Mueen (1999) Earnings Differential in Public and Private Sector in Pakistan. Islamabad: Pakistan Institute of Development Economics. (Mimeographed.)

Oaxaca, R. (1973) Male-female Wage Differential in Urban Labour Markets. International Economic Review 14:3 693-709.

Shabbir, Tayyeb (1991) Sheepskin Effect in the Returns to Education in a Developing Country. The Pakistan Development Review 30:1 1-19.

Shabbir, Tayyeb (1994) Mincerian Earnings Function for Pakistan. The Pakistan Development Review 26:4 687-696.

Shabbir, Tayyeb, and Alia H. Khan (1991) Mincerian Earnings Functions for Pakistan: A Regional Analysis. Pakistan Economic and Social Review 24: 99 111.

Spence, Michael A. (1974) Market Signalling: Informational Transfer in Hiring and Related Screening Processes. Cambridge, Mass: Harvard University Press.

Yaqoob, M. (1997) Factors Affecting Poverty in Pakistan, Poverty Alleviation in Pakistan: Present Scenario and Future Strategy (ed.) Institute of Policy Studies and Friedrich Ebert Stiftung. 


\section{Comments}

This paper is an attempt to compare the earning profile of individuals graduated from private school vis-à-vis government schools. It inquires into the differences in earnings stemming from differences in the human capital and structure of payments. The author derived results first, by simply presenting the averages of some key variables and secondly by following a conventional OLS estimators. The general conclusion of the paper is well expected i.e., private school graduates are doing better than government school graduates. Using this opportunity, I wish to make some following comments on this paper:

1. It seems to me that the title of the paper is not consistent with the analysis presented in it. The author seems too confident to be measuring productivity of workers with their income. According to neoclassical theory nominal income is equal to marginal revenue product, which is defined as price times marginal productivity. It is possible for someone to have low income in spite of high marginal productivity. Furthermore, it is also quite debatable that education, after certain years of schooling, does enhance the productivity of the worker. The number of years of schooling merely serve as a signal for ability. It would have been better if a different title could be given to this paper, the more consistent with differences in income of different kinds of graduates.

2. Throughout his analysis the author did not take time to define what he meant by school. Does schooling mean ten years of schooling or twelve years of schooling? Similarly, initially the author did mention about three types of schools in Pakistan-government school, public school, and private school. However, later on he just concentrated on public schools and private schools.

3. In the first part of his paper, the author compares the differences in income of public versus private school graduates by taking simple averages. He reported the results in Table 1 and Table 2 of his paper. Since it is too risky to infer results from simple averages, these averages may be reported along with their respective standard deviations. Moreover, considering the sample size and the methodology involved in collecting the data, the author could have tested, using simple $t$-test, if these earning averages were statistically different from each other or not. Furthermore, it seems to me not a very good idea to compare income averages on absolute terms. It is a common observation that people prefer low income but less risky jobs to high income but risky jobs. If we accept this fact then one of the conclusion of the paper might be that private school graduates prefer risky but high income jobs. 
4. In Table 4 the author reported the average monthly income of graduates having education less than 10 years, just 10 years, and having education greater than ten but less than 13 years. In my opinion it does not matter that someone studied in private school or pubic school if he spent less than 10 years in the school. Such cases may be dropped from the analysis.

5. In the second part of the paper, the author has done a regression analysis. He estimated four regression equations and inferred many things. I wish to make the following comments on this part of the paper:

(i) It could have been better if the author reported the exact form of equation in the text. It is not so clear that he is regressing the log of earning variable on variables which are expressed in logs (except the dummy variables) or they are expressed in level forms.

(ii) The author has included quite a few variables as explanatory variables, which has its own advantages and disadvantages.

(iii) The author reported that he has used Chow test to confirm the structural difference in returns for public and private school graduates by using a single equation. It could have been better and more reliable if the author had specified two different regression equations, one for public and one for private school graduates. He could then nest these equations by using dummy interactive variables. Finally, by estimating restricted and unrestricted residual sum of squares he could use the $F$ statistic to test the number of hypothesis.

(iv) The author has measured education as a quantitative variable. He even reported a result, for example that "for public school graduates an additional year of schooling raises the earnings by 14.2 percent whereas it contributes only 9.6 percent additional earnings for public school graduates". As a matter of fact college/school education is a qualitative variable not a quantitative variable. A person always get benefits and qualifies for certain jobs on the basis of diplomas and degrees. An additional year of schooling makes no sense unless it earns some diploma or a degree. It must be the case if the author ranked education according to diploma and degree.

6. Apart from above comments I also wish to make the following general comments on this paper:

(i) I found that the presentation of the paper needs some improvement. For example Equation (2) reported in the text deserves more explanation. Similarly, the author may explain the entries written in parenthesis in Table 3 and Table 4. Some omission is also found in the paper.

(ii) Decomposition of earnings differentials section of the paper is not clear at all for the general reader. The author did not explain one single entry 
reported in Table 7 of the text. Similarly, the definition of "difference in wage structure" and the method of measurement of "worker average endowment" are missing.

(iii) Apart from basic schooling, I believe that there are many other important factors which contribute to someone's earnings. For example, scoio-economic conditions, person's last degree, foreign qualification, etc., all play a decisive role in career building. The paper may include such variables while determining the wage differences.

International Islamic University,

Syed Zahid Ali

Islamabad. 